\title{
HOW DO PRIMARY TECHERS RESPOND TO INTRODUCTION OF BASICS OF COMPUTER SCIENCE INTO SCHOOL CURRICULA OF ICT
}

\section{Jiř́ VANÍČEK}

\begin{abstract}
The article focuses on basics of computer science education at primary school. The trend of recent years is to reintroducing computer science kontent into school curricula. The question is whether topics of basic sof algorithmisation and understanding of information are comprehensible for primary school teachers, who have undergone no training in computer science and how they respond to them. The paper reports about new textbook verification project in which pre-service teachers were trained to teach these topics. The results could shed more light into understanding how teacher builds up his/her pedagogical content knowledge in the area of propaedeutics of computer science.
\end{abstract}

Key words: primary school, computer science education, ICT curricula, teachers education

\section{JAK REAGUJÍ UČITELÉ 1. STUPNĚ NA ZA VÁDĚNÍ ZÁ- KLADŮ INFORMATIKY DO VÝUKY ICT}

Abstrakt: Článek zaměřuje pozornost na výuku informatiky na 1. stupni ZŠS. Trendem posledních let v zahraničí je (znovu)zavádění informatického obsahu do školního kurikula. Je otázkou, zda témata základů algoritmizace a porozumění informacím jsou srozumitelná učitelům, kteří neprošli žádným informatickým vzděláním, a jak na ně reagují. Článek podává zprávu o projektu verifikace nové učebnice informatiky na budoucích učitelích 1 . stupně ZŠ, kteří byli připravováni na výuku těchto témat. Výsledky mohou vnést více světla do porozumění, jak učitel buduje svoji didaktickou znalost obsahu v oblasti propedeutiky informatiky.

Klíčová slova: primární vzdělávání, výuka informatiky, kurikulum ICT, prríprava učitelů 


\section{Informatika a ICT}

Dovolíme si článek zahájit terminologickým úvodem, abychom objasnili, jak dále budeme vnímat rozdíl mezi termíny informatika (computer science) a ICT (information technology) na úrovni školského prostředí. Informační technologie podle slovníku Foldoc [1] jsou aplikací počítačových systémů; termín informatika (computer science) je obvykle vyhrazen pro teoretičtější, akademické aspekty práce na počítači.

V Německu je podle Schubertové a Schwilla vnímána výuka ICT jako rámec základního vzdělávání v oblasti informatiky, komunikace a informačních technologií [2]. Na Slovensku je podle Blaha oblast ICT chápána jako zvládnutí technologií, jako předstupeň informatiky [3]. I my $\mathrm{v}$ tomto článku budeme vnímat ovládání ICT jako součást, předstupeň informatického poznání. Nevnímáme tedy ICT a informatiku jako dva různé obory.

Od oboru ICT můžeme školní informatiku odlišit základním přístupem $\mathrm{k}$ počítačům, který Kalaš a kol. [4] uvádí jako autorský na rozdíl od uživatelského $\mathrm{v}$ prrípadě ICT. Tento rozdíl se promítá do cílů výuky, který můžeme vnímat jako snahu o porozumění počítači (informatika) na rozdíl od ovládání počítače (ICT).
2 Vyučovací předmět ICT na 1. stupni ŽS

Informační a komunikační technologie jsou jednou z devíti vzdělávacích oblastí na základních školách [5]. V České republice je povinně vyučován prèedmět ICT i na 1. stupni ZŠ. Očekávání daná školským zákonem z r. 2004, že všichni absolventi 1. stupně jsou vybaveni základními kompetencemi v ovládání počítačů a práce $s$ informacemi, však nejsou naplňována, realita bývá plánům vzdálena. Ačkoliv předmět ICT může být vyučován v kterémkoliv ročníku od prvního do pátého, drtivá většina škol zařazuje předmět až nyní do pátého, posledního možného ročníku. Zavádění nového předmětu provází shoda nepř́ijemných komplikací:

1. předmět nikdy předtím nebyl na 1. stupni vyučován, na školách není žádná tradice a nejsou zkušenosti, jak tento předmět vyučovat;

2. současně realizovaný přechod na nový způsob vytváření školních vzdělávacích programů a přesunu zodpovědnosti za vytvořené a realizované kurikulum na učitele, potažmo školu, na rozdíl od ostatních vyučovacích předmětů ztížil vytvoření tohoto předmětu;

3. učitelé 1. stupně nejsou odborně ani didakticky prripraveni ani připravováni; nebyly 
pořádány žádné vzdělávací kurzy organizované metodickými orgány ministerstva;

4. učitelům chyběly metodické materiály a žákům učebnice, neprobíhal výzkum v této oblasti;

5. učitelé 1 . stupně na mnoha vysokých školách nebyli a dosud nejsou prripravováni $\mathrm{v}$ oblasti didaktiky informačních technologií.

Aktuální stav výuky ICT na 1. stupni ZŠ můžeme dokumentovat následujícími dvěma zjištěními:

6. Podle odpovědí na otázku „Kdo vyučuje informatiku na 1. stupni vaší školy?“, kterou jsme v roce 2013 položili učitelům - školním koordinátorům soutěže Bobřík informatiky, 63 respondentů odpovědělo tak, že z 58 \% vyučoval informatiku učitel 2. stupně, pouze $\mathrm{v}$ méně než polovině př́ípadů to byl učitel 1. stupně. To není dobrá situace $\mathrm{z}$ důvodu, že předmět je vyučován učitelem, který není připraven na výuku s danou věkovou kategorií žáků. Protože učitel ICT nepatří mezi komunitu učitelů 1. stupně na škole, je tento předmět odtržen od ostatních, takže je větším rizikem, že počítače $v$ ostatních předmětech používány nebudou vůbec. Zároveň zde hrozí riziko, že učitel 2. stupně bude do své výuky mechanicky přenášet kurikulum a metody určené starším žákủm.

7. Z průzkumu mezi neúplnými školami v ČR, které provedl Pyszko v r. 2013, vyplývá, že ne každá škola má na 1 . stupni vůbec povinný předmět ICT zaveden a daná tématika je vyučována jako průřezové téma. Např. V Ústeckém kraji je takových škol $48 \%$, ve Zlínském $32 \%$, což je alarmující číslo. [6].

\section{Zařazování informatiky do výuky}

Současně s procesem, jehož výsledkem je, že každý absolvent 1 . stupně ZŠ má ovládat počítač na uživatelské úrovni, můžeme v posledních letech ve světě pozorovat jiné změny, které mají dopad na školské kurikulum. Jde o tendenci opětovně zařazovat do výuky práce s počítačem nejen témata týkající se digitální gramotnosti, ale též témata ze základů informatiky. ACM výbor pro kurikulum K-12 v USA již před 10 lety požadoval zařadit základní pojmy informatiky (např. porozumění algoritmu) do primárního vzdělávání [7].

Nemůžeme brát za směrodatné, že v České republice se základy informatiky $\mathrm{v}$ dokumentech o vzdělávání na 1. stupni neobjevují a např. o algoritmech se píše převážně v matematice, ve vzdělávací oblasti ICT je pouze zmínka, že 
„,̌̌ák má využívat při interakci s počítačem algoritmické myšlení“ [5]. V zemích jako V. Británie, Slovensko, Polsko vidíme jiný př́istup. Např. v Británii je od r. 2014 zaváděn nový předmět Computing již od 1. stupně ZŠ [8] a upouští se od termínu ICT i jeho vzdělávacího obsahu. Na Slovensku jsou ve státních vzdělávacích dokumentech pro 1 . stupeň ZŠ minimálně dva z pěti tematických celků orientovány $\mathrm{k}$ základům informatiky jako vědního oboru a propedeutice informatických pojmů [9].

Jako jednu z významných mezinárodních aktivit, která prosazuje větší podíl informatiky v základním a středním školství formou jsoucí mimo školní kurikulum, můžeme zmínit soutěž Bebras pro žáky základních a středních škol. Soutěž vznikla před 9 lety a v České republice se pořádá od r. 2008 pod názvem Bobřík informatiky. Zájmu o téma soutěže svědčí každoroční veliký nárůst počtu zemí i soutěžících $v$ této soutěži [10]. Soutěž přitom není zaměřena na informační technologie ani na uživatelský přístup, preferuje otázky z oblastí algoritmizace, porozumění informacím a jejich reprezentacím, mezi témata patří též řšení problémů a informační gramotnost. I tato soutěž se rozšiřuje i směrem k mladším ročníkům, jako první zavedli soutěž pro 1 . stupeň ZŠ na Slovensku v r. 2011. V České re- publice máme za sebou dva ročníky existence kategorie Mini pro 4. a 5. ročník ZŠ, v r. 2013 se jí zúčastnilo přes 6000 žáků, z toho $48 \%$ dívek [11]. Touto formou se mohou děti i jejich učitelé na věku prrizpůsobených úlohách dostat $\mathrm{k}$ informatickým úlohám a představit si tak, jakou povahu mají problémy, kterými se informatika zabývá.

\section{Inovace výuky ICT na 1 . stupni ZŠ pomocí učebnice}

V nové učebnici informatiky pro 1. stupeň, která vyšla v r. 2012 [12], jsme se snažili reagovat na výše popsané trendy. Do učebnice jsme zařadili témata nejen ze základů ovládání počítače, ale též témata propedeuticky informatická, týkající se algoritmizace a porozumění informacím. Vedlejším cílem byla i snaha o ovlivnění učitele a jeho rozhled $\mathrm{v}$ oboru. Brali jsme $\mathrm{v}$ potaz tvrzení E. J. Rohaanové ,učitelé primárního vzdělávání, kteří jsou vzděláváni $\mathrm{v}$ širokém spektru předmětů, potřebují důkladnou znalost obsahu předmětu ICT, aby věděli, která témata řešit a jak je řešit ve své výuce tohoto předmětu“ [13] i fakt, že tito učitelé nejsou nijak vzděláni v oboru informatika.

Tato učebnice informatiky pro 1. stupeň obsahuje osm kapitol, z nichž je pět kapitol z oblasti ICT, které jsou věnovány ovládání aplikací, kreslení, psaní a Internetu (včetně komunikace), dvě kapitoly z oblasti základů informatiky (na- 
zvané programování, informace) a jedna průřezová kapitola, věnovaná učení se s počítačem a projektům s použitím technologií.

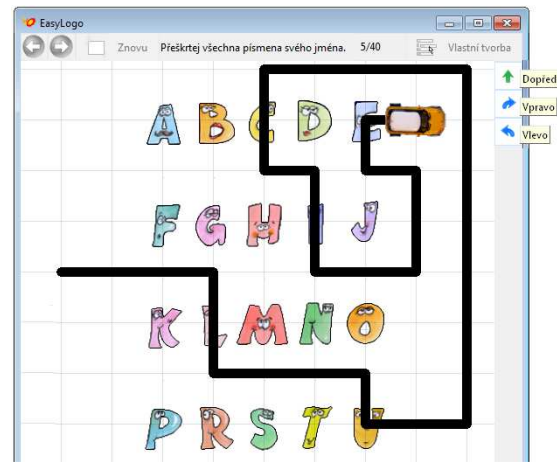

Obr. 1: Propedeutika programování - ovládání autíčka pomocí okamžitě vykonávaných př́kazů. Zadání úlohy: projed' všemi písmeny tvého jména tak, jak jdou za sebou.

Jak byly koncipovány informatické kapitoly? Kapitola ,programování“ seznamuje žáky se základy algoritmizace na sadě praktických úkolů $\mathrm{v}$ prostředí aplikace EasyLogo, jejímž autorem je L. Salanci [14]. Jde o jednoduchý mikrosvět na bázi Logo, v němž uživatel pomocí př́kazů ovládá postavu, která se podobně jako „logovská želva“ pohybuje a kreslí (obr. 1). Žák se seznámí $\mathrm{s}$ principem tvorby programu jako sledu prŕkazů s parametry, s jednoduchou algoritmickou strukturou cyklu se známým počtem opakování a jed- noduchým použitím procedur jako podprogramů. Prostředí EasyLogo bylo vybráno především s ohledem na učitele, protože obsahuje sadu daných úkolů a sama kontroluje žákovu práci. Učitel pak stojí v roli manažera a pomocníka, nevyžaduje se od něho, aby předkládal úkoly či vysvětloval látku. Uzavřené výukové prostředí těchto úloh tak nevytváří u učitele nejistotu a podle slovenských zkušeností je učiteli dobře prrijímáno. Praktické činnosti žáků jsou doplněny ,unplugged“" aktivitami, v nichž žák vytváří př́kazy pro spolužáka pro vykonání nějakého úkonu (např. ovládá žáka jako robota), a jednoduché algoritmické otázky.

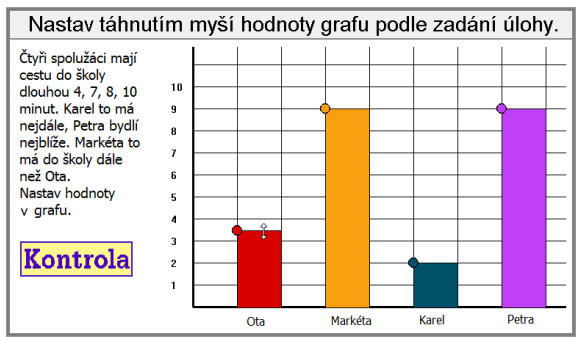

Obr. 2: Výuková aktivita z oblasti porozuméní reprezentacím informací. Žák „ručně“ pomocí myši nastavuje hodnoty na grafu, aby odpovídaly textu $v$ levém sloupci, počítač kontroluje.

Kapitola o informacích se zabývá informacemi $\mathrm{z}$ hlediska jejich obsahu (co nám věci kolem nás ř́kajî), reprezentace (signály, 
symboly) a typu digitálního média (text, audio, video). Dále se tato kapitola zabývá reprezentacemi informací v podobě informatických struktur seznamů, tabulek a pomocí grafů. Vedle uživatelských dovedností (např. psaní do tabulky, formátování seznamu, vytvoření grafu z tabulky) zde žáci získávají kompetence týkající se porozumění těmto strukturám. Jsou zde zařazeny aktivity, $\mathrm{v}$ nichž se učí rozlišovat číslovaný a nečíslovaný seznam, volit vhodný tvar tabulky pro zápis dat, správně zapisovat tyto údaje do tabulky, volit vhodný typ seznamu, číst informace $\mathrm{z}$ grafu a také vytvářet graf „ručně“, bez automatických nástrojů počítače (obr. 2). Aktivity zpracování informací směřjí $\mathrm{k}$ následnému využívání tabulek a grafů ve vlastních výzkumech zahrnujících jednoduché zpracování dat (měření, ankety).

\section{Jak reagují budoucí učitelé 1.} stupně?

Při vytváření obsahu učebnice nás zajímaly otázky: jakým zpo̊sobem přiblížit informatiku budoucím učitelům, kteří nejsou v tomto oboru vzděláni, jakým způsobem a zda vůbec akceptují informatická témata. Dalšími otázkami bylo, zda konkrétní úlohy, připravené do nové učebnice, budou pro ně srozumitelně a smysluplné, zda studenti budou rozumět zadání i informatickému pozadí.
Jednotlivé aktivity, zařazené do učebnice, jsme mohli průběžně testovat na studentech učitelství 1. stupně na Pedagogické fakultě Jihočeské univerzity. Celkem trri běhy výzkumu proběhly $\mathrm{v}$ rámci předmětu Didaktika informačních technologií pro primární vzdělávání o rozsahu 1 préednášky a 1 cvičení týdně v 1 semestru. Předmětem prošlo za 3 roky 124 studentů. Žádný z nich neměl předchozí informatické vzdělání, všichni absolvovali pouze středoškolskou výuku ICT. Na vysoké škole absolvovali jeden povinný prredmět $\mathrm{z}$ oblasti informačních technologií Technologie ve vzdělávání, kde pořizovali a zpracovávali fotografie, audio a video a učili se ovládat interaktivní tabuli. Všichni respondenti absolvovali základní test informační gramotnosti, svojí úrovní srovnatelný s ECDL-START.

Výuka probíhala velice praktickou cestou. Studenti při cvičeních dostávali náročnější úlohy $\mathrm{z}$ učebnice, tedy úlohy stejné jako jejich budoucí žáci, často pracovali „,v roli žáka“. Přednášky byly věnovány jednotlivým tématům, jednotlivé předkládané metodické postupy byly většinou dokumentovány na konkrétních úlohách a aktivitách $\mathrm{z}$ učebnice, často na úlohách, které předtím mohli studenti sami vyzkoušet v roli žáků a mít $s$ nimi vlastní zkušenost. Do programu předmětu byly zařazeny i základy robotiky 
pomocí robotických stavebnic LEGO WeDo (obr. 6), ovládanými z programovacího prostředí Scratch. V nich studenti vytvářeli vlastní velmi jednoduché programy pro ovládání již vytvořených robotů (např. „,bezpečný“ větrník, reagující na přiblížení ruky vypnutím). Součástí předmětu bylo též seznámení s robotickými hračkami Bee-bot, které umožňují oddálení vykonání série př́íkazů $\mathrm{k}$ pohybu. $\mathrm{Na}$ závěr semestru měl každý student vytvořit vlastní sadu úloh pro výuku některého probíraného tématu.

Pro zjištění zpětné vazby od studentů jsme použili metody zúčastněného pozorování, analýzu studentských prací a rozhovory s některými studenty po absolvování kurzu.

\section{Jednotlivá zjištění}

\section{Celkový přístup}

U studentů se výrazně zvedl zájem ve chvíli, kdy se dozvěděli, že jde o povinný předmět školního kurikula a že jej budou muset vyučovat.

Celkově studenti vnímali zvolený způsob výuky příznivě, měli zájem o hravé, praktické aplikace a úlohy ze života. U takových úloh jim připadalo vše srozumitelnější než teoretické pasáže. Jakmile jsme při přednášce navodili teoretické téma, studenti měli tendenci naučit se tuto látku zpaměti s cílem ji reprodukovat, nikoliv ji používat.

Postoj studentů k tomuto předmětu můžeme považovat za kladný, protože předkládané aktivity brali jako pro ně smysluplné, mentálně nepř́liš náročné. Nepozorovali jsme, že by studenti odmítali zvolený přístup.

\section{Programování}

Studenti neměli žádnou potíž s termínem programování, nebylo pozorováno, že by se programování obávali. Při řešení programovacích úloh vnímali svoji činnost, jako že programují. U této skupiny studentů nemůžeme potvrdit obavy z predpojatosti veřejnosti vưči termínu programování.

Lze říci, že zhruba polovinu studentů práce $\mathrm{v}$ prostředí EasyLogo viditelně bavila, byli jsme svědky jejich emocionálních reakcí na uživatelskou př́jemnost prostředí i na situace, kdy se jim podařilo vyřešit složitější úlohu nebo vznikl vizuálně pěkný výsledek. Při závěrečném testování byli všichni studenti schopni vyřešit obtížnější algoritmické úlohy s použitím cyklu (např. vytvoř program, kterým želva dokreslí stromům kmeny - obr. 3). 

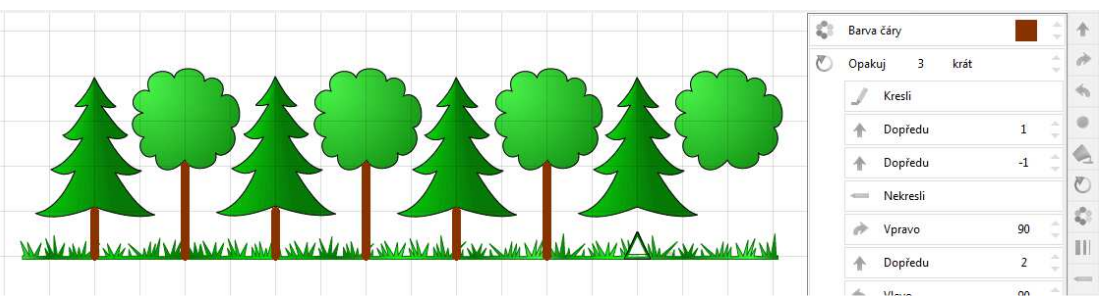

Obr. 3: Programovací aktivita v EasyLogo, kreslení kmenů ke stromům s použitím cyklu, vpravo je sestaven program

Studenti neradi používali cyklus, především strukturu prríkazu Opakuj, když se v ní nacházelo více př́kazů. Teprve dodatečně přidané restrikce, že délka programu nemůže být delší než 15 řádků, aby byl celý vidět $\mathrm{v}$ okně aplikace, je přiměla používat prríkaz Opakuj. Stejné to bylo při použití vnořených procedur, kde muselo být $\mathrm{v}$ zadání uvedeno, že je nutno použít předem připravené procedury.
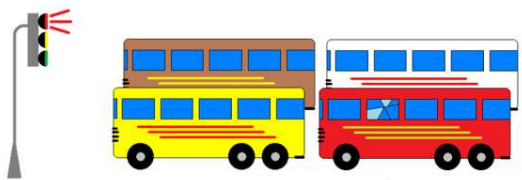

Obr. 4: Problémy s orientací $v$ kontextu zadání úlohy - je autobus s rozbitým sklem vlevo od bílého, nebo pred bílým autobusem?

\section{Problém prostorové orientace}

Naopak nás překvapily problémy nemalé části studentů s orientací, co je vpředu, co je vlevo apod. Napřr. u úlohy s autobusy umístě- nými v garáži, které se mají obarvovat podle instrukcí daných jejich vzájemnou polohou, někteří studenti nedokázali určit, zda je např́klad červený autobus před žlutým nebo stojí vlevo od něho (obr. 4). Po těchto zkušenostech jsme úlohu v učebnici přeformulovali a přidali semafor na křižovatce, aby směr jízdy autobusu jasněji stanovoval směr ,před“" a ,za“".

Podobnou situaci vyvolala úloha, v níž na obrázku řady jedoucích aut (na pohled stejných zepředu jako zezadu) se mělo určit, které auto jede před černým autem (obr. 5). Někteří studenti trvali na tom, že ,před“ je vždy vpravo. Patrně přejali pozicování aut z postavení slov při psaní textu, protože tento prístup jsme mohli pozorovat u jiných nesouvisejících úloh. Žádnou argumentací se je nepodařilo přesvědčit, že auta mohou též jet zprava doleva. Zdá se, že tyto problémy jsou geometrického rázu a nemají tedy informatické souvislosti, ovšem tyto nečekané problémy 
mohou řadu úloh $\mathrm{z}$ reálného světa na řazení a tř́ídění diskvalifikovat.

\section{Práce s informacemi, grafy}

Při vytváření grafů pomocí online aplikace měli někteří studenti potíže s tím, jak vepsat data správně do tabulky, ze které se generoval graf. Tato kompetence je založena na pochopení tabulky jako datové struktury. Studenti číselné hodnoty zapisovali do sloupce, určeného pro popisky položek, a když se graf zobrazil špatně, někteří si s tím nedokázali sami poradit.

\section{Kreativita}

Studenti obecně přijímali lépe problémové úlohy, a to i při programování, než úlohy na tvořivost. Vlastní studentské projekty byly málo nápadité a často pouze variovaly úlohy, probírané na seminářích.

\section{Informatika jako disciplína}

Studenti prŕliš nerozlišovali informatiku od ostatních školních předmětů. Na jednu stranu vše, co se týkalo práce na počítači, brali jako informatiku, v úlohách vytvořených studenty se často vyučovalo učivo z jiného předmětu. Např. při úpravách textů věnovali větší pozornost gramatickým než typografickým chybám, při kreslení často dbali na správné použití kreslicích nástrojů z výtvarného než ICT pohledu (např. preferovali vizuálně „hezčíc obrázek, vytvořený pouze několika základními nástroji tužka, výplň). Nenabyli jsme dojmu, že by budoucí učitelé byli schopni vytvářet originální výukové objekty pro podporu výuky informatiky.

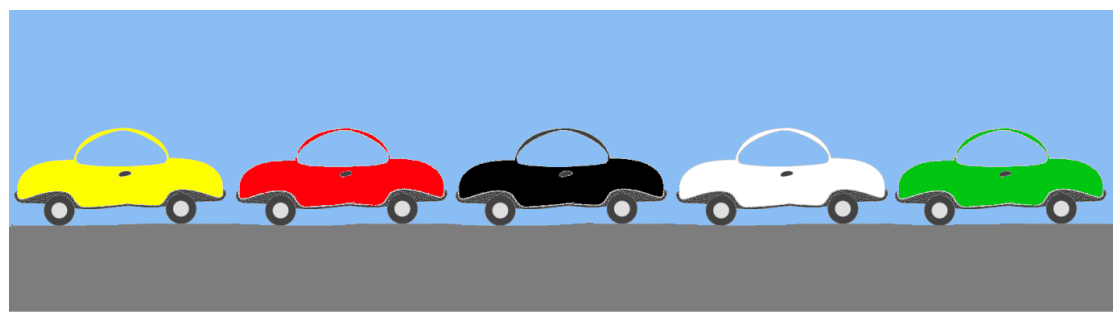

Obr. 5: Problém orientace: které auto stojí před černým autem?Někteři studenti vnímali, že auta mohou jet pouze doprava (a proto je správně pouze bílé auto). 


\section{Závěry}

Pokusili jsme se odpovědět na otázky, jakým způsobem didakticky připravovat studenty učitelství 1 . stupně, kteří jsou bez předchozího informatického vzdělání (a nemají také ani specializované vzdělání v oblasti ICT). J. Twyford a E. M. Järvinen $\mathrm{V}$ závěrech kvalitativní studie doporučují pro žáky 1. stupně přístup „od ruky“ a tvrdí, že žáci mohou nejlépe porozumět technologiím, pokud prezentované problémy jsou ze života“ [15]. Z našich zkušeností můžeme toto zjištění potvrdit. Zdá se, že užitečným prístupem bude seznamovat budoucí učitele se základy informatiky na tématech a úlohách blízkých jejich žákům, to znamená zařazovat manipulativní, praktické úlohy, ke kterým jim bude $\mathrm{v}$ komentárích vysvětlováno, co má úloha společného s informatikou.

Budoucí učitelé 1 . stupně ve zkoumaném vzorku nemají problém s algoritmickými úlohami, jestliže za nimi vidí konkrétní ovládání pohybu nějakého objektu. Podobně přirozeně akceptují téma porozumění informacím a jejich reprezentacím, pokud v konkrétní úloze vidí obecný přínos ke vzdělání žáka. Lze říci, že informatickou složku vzdělání vnímají daleko více v kontextu celého vzdělávání, než v kontextu oboru.

Prokázalo se, jak je těžké budovat didaktickou znalost obsahu bez řádné znalosti obsahu po odborné stránce. Současně je zřejmé, že řešením nebude vzdělávání učitelů 1. stupně v oboru informatika, protože jejich neznalosti jsou velice hluboké. Zde musíme spoléhat na středoškolské vzdělávání a jeho budoucí orientaci směrem k základům informatiky ve vzdělávací oblasti informatika a ICT, př́ípadně systém školení pro učitele $\mathrm{z}$ praxe. Jestliže chceme, aby učitelé 1 . stupně správným způsobem zahrnovali do svého kurikula předmětu ICT také základy informatiky, musí být $\mathrm{v}$ tomto směru metodicky vedeni, at' již učebnicemi, nebo lépe proškolením. Budoucí učitelé v nabízeném kurikulu více než oborovou správnost sledují, zda aktivity budou pro žáky atraktivní, hravé a presto budou mít za cíl něco naučit. Tento aspekt je důležité $\mathrm{v}$ př́pravě učitelů neopominout.

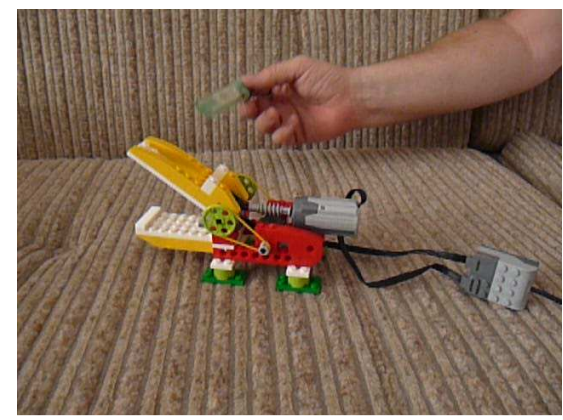

Obr. 6: Robotická stavebnice LEGO WeDo, ovládání tlamy krokodýla programem pomocí senzoru, který rozezná blizkost predmětu. 
Robotické aktivity doplňovaly téma základů algoritmizace.

Poznámka: Výzkum byl podpořen grantem GAJU 017/2013/S.

\section{Literatura}

[1] Information technology [online]. In Howe, D. Free Online Dictionary of Computing [cit. 2013-10-01]. Dostupné na:

http://foldoc.org/ information+technology.

[2] SCHUBERT, S., SCHWILL, A. Didaktik der Informatik. 2. vydání. Heidelberg: Spektrum Akademischer Verlag, 2011.

[2] BLAHO, A. Informatika v štátnom vzdelávacom programe. In Kalaš, I. (ed.) Sborník DidInfo 2012. B. Bystrica: Univerzita Mateja Béla, 2012, s. 7-14

[4] KALAŠ, I., KABÁTOVÁ, M., BRESTENSKÁ, B., GULAŠA, R., CHACHALÁNOVÁ, M., PALÚCHOVÁ, K., PEKÁROVÁ, J., SZARKA, K., VANÍČEK, J., WINCZER, M. Premeny školy $\mathrm{v}$ digitálnom veku. Bratislava: Slovenské pedagogické nakladatel'stvo, 2013, $256 \mathrm{~s}$.

[5] Kol. Rámcový vzdělávací program pro základní vzdélávání. Praha: VÚP, 2007.

[6] PYSZKO, D. Využití informačních a komunikačních technologií ve výuce na neúplných základních školách. Ostrava, 2013. rigorózní práce $(\mathrm{PhDr}$.). Ostravská univerzita v Ostravě. Pedagogická fakulta. Vedoucí práce: Kapounová, J. [7] TUCKER, A. a Model Curriculum for K-12 Computer Science: Final Report of the ACM K-12 Task Force Curriculum Committee. New York: The Association for Computing Machinery, 2003.

[8] Computing. Programmes of study for Key Stages 1-4. National curriculum in England. [online]. Computing at School Working Group, 2013. [cit. 2013-12-11]. Dostupné z:

http://media.education.gov.uk/asset s/files/pdf/c/computing\%2004-0213_001.pdf.

[9] BLAHO, A., SALANCI, L. Informatics in Primary School: Principles and Experience. In Kalaš, I. and Mittermeid, R. T. (eds.) ISSEP 2011, s. 129-142, 2011

[10] Bebras, mezinárodní web informatické soutěže (online). [cit. 2013-01-13] URL:

<http://www.bebras.org/countries>

[11] Bobř́k informatiky, web soutěže (online). [cit. 2013-01-10] URL: 〈http://www.ibobr.cz>

[12] VANÍČEK, J. Informatika pro 1. stupeň ZŠ. Brno: Computer Press, 2012, 88 s.

[13] ROHAAN, E. J., TACONIS, R., JOCHEMS, M. G. Reviewing the relations between teachers' knowledge and pupils' attitude in the field of primary technology education. International Journal of Technology and Design Education, r. 20 č. 1, 2010, s. 15-26. 
[14] SALANCI, L. EasyLogo discovering basic programming concepts in a constructive manner. In Clayson, J. E., Kalaš I. (eds.) Constructionist approaches to creative learning, thinking and education: lessons for the 21st century. Bratislava: Library and publishing centre Comenius University, 2010.

[15] TWYFORD, J., JÄRVINEN, E. M. The formation of children's technology concepts: a study of what it means to do technology from a child's perspective. Journal of Technology Education, Vol. 12 No. 1, 2000, s. 32-48.

doc. PaedDr. Jiří Vaníček, Ph.D. Katedra informatiky

Pedagogická fakulta Jihočeské univerzity, Jeronýmova 10

371 15, České Budějovice, ČR

Tel: +420 387773074

E-mail: vanicek@pf.jcu.cz

Web pracoviště: wvc.pf.jcu.cz/ki 